\title{
Koledokta semptomatik yabancı cisim
}

\author{
A symptomatic foreign body in common bile duct
}

R. Olga METIN, Erkan PARLAK, Bülent ÖDEMIŞ, Selçuk DIŞİBEYAZ

Türkiye Yüksek Ihtisas Hastanesi, Gastroenteroloji Kliniği, Ankara
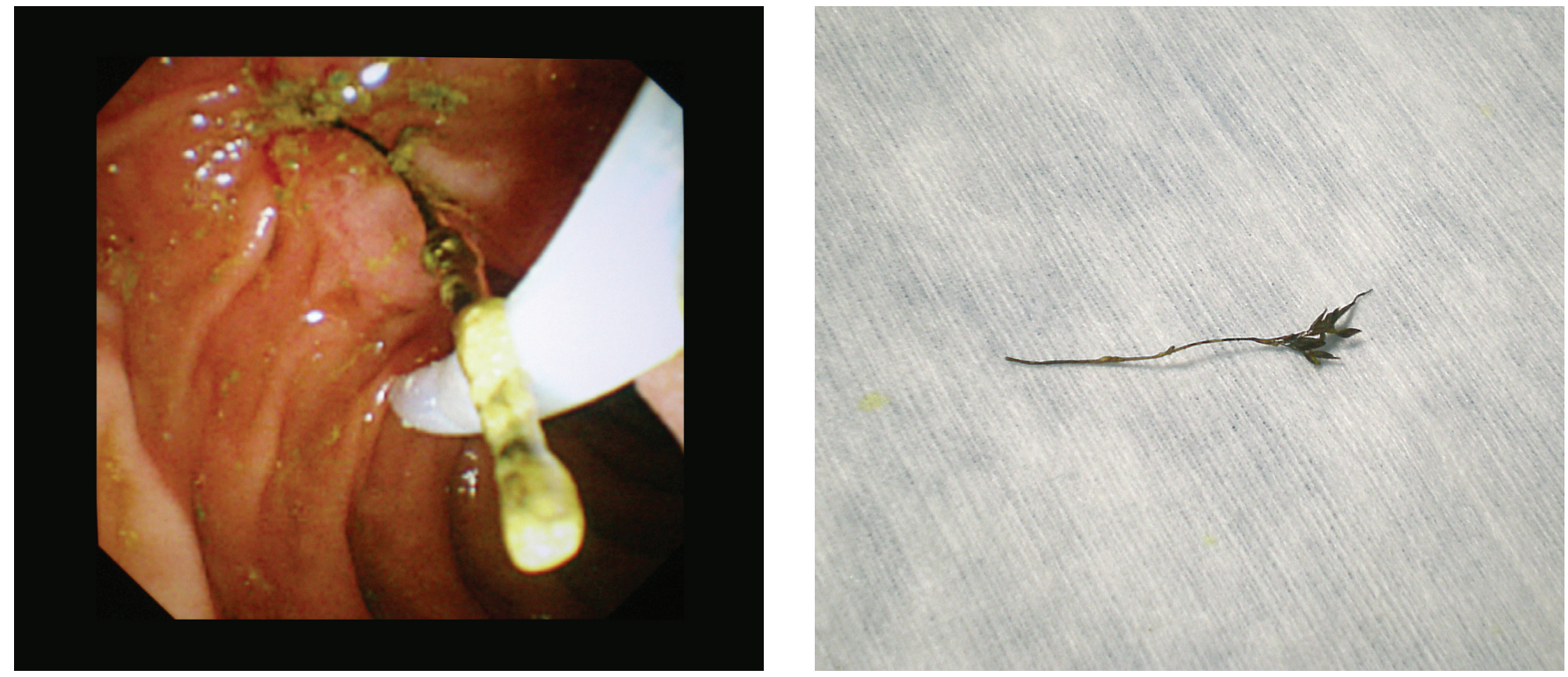

Oddi sfinkter disfonksiyonu ön tanısıyla 1 yıl önce endoskopik retrograd kolanjiyopankreatografi (ERCP) yapılan ve lümen içi patoloji saptanmayan hastaya terapötik amaçlı sfinkteretomi yapılmış. Karın ağrısı ile yeniden başvuran ve ERCP yapılan hastanın sfinkteretomisi büyütüldü ve koledok balonla kontrol edildi. Bu sırada yaklaşık $1.5 \mathrm{~cm}$ boyunda ince uzun iplik benzeri, öncelikle daha önce geçirmiş olduğu operasyondan kalan sutur materyali olduğu düşünülen yabancı cisim çıkartıldı. Bu cisim dışarıda incelendiğinde uzun saplı bir bitki olduğu anlaşıldı. Bu ot parçasının 1 yıl önceki sfinkteretomi sonrası koledoğa girdiği ve hastada klinik semptomlara yol açtığı kanaatine varıldı. 